many, was rightly considered not to be in point, because in those cases it was alleged that the decisions had been induced by fraudulent testimony. In the instant case, the Tribunal draws a distinction between "essential error" and "manifest error," permitting revision only in the latter case. The distinction appears to be rather casuistic. What is "manifest" is, after all, a relative term, with a personal connotation. The Tribunal has softened the blow somewhat by remarking by way of dictum that even if it had the power to reopen the question, it would have reached the same conclusion as in its previous decision. It will be remembered that the Tribunal intimated that another result might have been reached if the claimants had been private individuals instead of the government of a sovereign state. The present writer believed then and still believes that this distinction is not cogent, especially where the expenditures were principally incurred in obtaining scientific expert testimony of the nature and extent of the damage over a long period of time, the legal obligation having been recognized.

The Tribunal found that no actionable damage by the fumes was proved to have occurred between October 1, 1937, and October 1, 1940. Judgment on this point having gone against the United States, it was to be expected that its claim for costs in the preparation of the unsuccessful part of its case should not be allowed. In view of the very large expense in obtaining the necessary technical proof in cases of this kind, it will be advisable to make proper provision for this in the compromis in all similar future arbitrations.

A most important part of the decision consists in recommendations for a permanent régime in the operation of the Trail Smelter as provided for in Article III of the convention. The Tribunal found that damage may occur in the future unless operations be subject to some control. To prevent this, the Tribunal decided that a régime or measure of control shall be applied and shall remain in full force unless modified after December 31, 1942, by the opinion of scientists appointed and functioning as particularly set forth in the decision.

The decision represents most painstaking work on the part of the three members of the Tribunal, Jan Hostie (of Belgium), Charles Warren (of the United States), and R. A. E. Greenshields (of Canada), as it required careful consideration of the voluminous reports of the technical consultants. The arbitrators and the two governments concerned may be congratulated upon bringing to an end in a constructive and permanent manner this long-pending controversy.

Arthur K. KuHN

\title{
SOVEREIGNTY IN EXILE
}

The appointment of the American Ambassador to Poland, Mr. Biddle, as diplomatic representative to Belgium, The Netherlands, Norway, and Yugoslavia, raises a nice point of international law and procedure. Is this unique embassy to governments-in-exile in England a fiction or a fact? 
When Poland was occupied by Germany, Ambassador Biddle accompanied the Polish Government in its flight and re-established the Embassy near the remnant of Polish sovereignty represented in London. This government exercises no authority whatever within the boundaries of Poland. Can it therefore be truly said that Poland still exists as a member of the family of nations?

The status of Norway and Yugoslavia is similar to that of Poland, but the situation of Belgium and The Netherlands is much different. The King of Belgium, it is true, is a German prisoner, while the Queen of The Netherlands is free to serve as the standardbearer of Dutch sovereignty. The significant fact in the case of both these countries, however, is that they possess vast colonial territories still under the direct administration of their respective governments in London. They continue to exist as international entities and are able to maintain diplomatic relations with other nations.

Poland, Norway, and Yugoslavia, on the other hand, have no territory left on which to find pied a terre. Their governments are in large measure simulacra, symbols rather than active administrative entities. And yet both Poland and Norway possess and control navies and merchant marines. Their airplanes and submarines are inflicting serious damage on Germany.

While the status of these governments-in-exile is unique and not identical in every case, it would seem clear that they are facts and not fictions. Until their countries shall have been definitely integrated with the German Reich they must be considered as international entities. Their sovereignty has not been extinguished. Its freedom of exercise has merely been restricted or suspended.

Military occupation by itself does not confer title or extinguish a nation. Nor does a proclamation of annexation so long as the claims of the occupying Power are effectively challenged and remain unrecognized. The Emperor of Abyssinia in exile never accepted the occupation of his country by Italy and now once again is its sovereign head. Such may be the good fortune of all those nations which have been over-run by the German armies.

The general conclusion we are warranted in reaching is that so long as a people do not accept military conquest; so long as they can manifest, in one way or another, their inalterable will to regain their freedom, their sovereignty, even though flouted, restricted, and sent into exile, still persists. They are entitled to maintain diplomatic relations with other nations until circumstances or reasons of state put an end to such relations. This relationship is moral as well as legal. The members of the family of nations cannot with honor abandon any independent free nation to international gangsters and pirates. If they are unable to give active help, they can at least be loyal friends and continue diplomatic relations with peoples who have become the victims of illegal aggression. The right of prescription cannot be conceded to freebooters, even though they hold their illgotten territorial gains for years. 
There is a still deeper significance to this anomalous condition of sovereignty in exile. There is no automatic extinction of nations. Military occupation may seem final and permanent, and yet prove to be only an interregnum, though a prolonged nightmare for the inhabitants. A nation is much more than an outward form of territory and government. It consists of the men and women in whom sovereignty resides. So long as they cherish sovereignty in their hearts their nation is not dead. It may be prostrate and helpless and yet revive. It is not to be denied the symbols and forms of sovereignty on foreign soil or diplomatic relations with other nations.

Article five of the resolutions of the Institut de Droit International on the subject of the "Recognition of New States and New Governments," adopted at Brussels in 1939, asserted that recognition was irrevocable, but also added that "it only ceases to have effect in case of the disappearance of one of the essential elements whose reunion was established at the time of recognition." These elements were defined as "the existence on a definite territory of a human society politically organized, capable of observing the rules of international law." If this pronouncement of international law and procedure were to be accepted as true, it might be difficult to justify the embassy of Mr. Biddle to all of these conquered countries in exile, with the exception of Belgium and The Netherlands. These "essential elements" of sovereignty would appear to have vanished in the case of Norway, Poland, Yugoslavia, as well as of Czechoslovakia and Greece. The conjunction of all these elements would not seem essential, however, to warrant a conquered people to maintain their sovereignty and to deserve the continued recognition of other nations. This sovereignty may be suspended, and in exile, a mere figment even of reality, derided and discouraged, and yet entitled to every respect. Ambassador Biddle in London therefore is not dealing with fictions: he speaks to those valiant standardbearers of sovereignty in England the language of faith and confidence as well as of inalienable, immutable rights.

Philip Marshall Brown

\section{THE HOMT SERVICE OF THE DEPARTMRNT OF STATE}

The World War placed renewed emphasis on the need of an improved foreign service to care for American nationals and their interests in other lands. The Rogers Act of 1924, the Porter Act of 1926, and the MosesLinthicum Act of 1931 met this need and provided for a foreign service reasonably adequate for our national needs. These acts did not, however, introduce any very radical reforms in the Department of State itself. It is true that a considerable number of the Foreign Service Officers were assigned for limited periods to the Department in order that they might aid in the transactions of our relations with the countries in which they had served and knew at first hand. A few of these officers resigned from the Field Service in order to accept positions in one of the divisions of the Department. 